\title{
Awakening the film censors archive in [CENSORED] (2018)
}

Claire Henry

DOI:10.15664/fcj.v19i0.2388

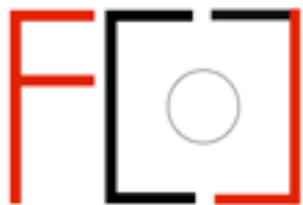

Frames Cinema Journal ISSN 2053-8812

Issue 19 (March 2022)

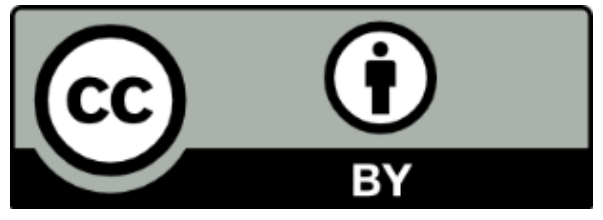




\section{Awakening the film censors' archive in [CENSORED] (2018)}

Claire Henry

[CENSORED] (2018) is a feature-length collage of clips which the Australian Film Censorship Board excised from international films imported between 1958 and 1971. Historian and artist Sari Braithwaite came across the collection of clippings in the National Archives of Australia (NAA) while working on a short film in 2014, which provided her inspiration and source material for [CENSORED]. In this essay, I argue that [CENSORED] documents an awakening of - and from - the censors' archive. The film evolves through sensory engagement with this archive, and in doing so, provides insight into the comparable - and sometimes complicit processes of film spectatorship, censorship, and audio-visual archival research. The thematic montages in Braithwaite's essay film capture the numbness generated by the archive's "neverending loop of more and more of the same" (as she describes the collection in the film's voiceover). Braithwaite's approach - involving compiling and recategorising a wealth of censored fragments (over 2000 clips from a total of 1991 film titles) according to theme rather than title - produces a new perspective not only into past practices of censorship but, more insightfully, into patterns of gendered dynamics and action in narrative cinema gleaned from the censorexcised film clips. Braithwaite's film mobilises "productive misuse", not for her original goal of damning censorship, but to reflect on cinematic fixations (including female nudity and sexual violence) and spectatorial implication. ${ }^{1}$

[CENSORED] exemplifies Catherine Russell's observation that "archive-based filmmaking can produce important and insightful knowledge about film history". ${ }^{2}$ A product of - and reflection on - Braithwaite's sensory and ethical engagement with the censor's archive, [CENSORED] is both a feminist "awakening" (in Russell's sense of the term) and an act of 
Frames Cinema Journal, Issue 19 (March 2022)

critical cinephilia, engaging in "destructive criticism" that leaves the cinematic "phantasmagoria in ruins". ${ }^{3}$ By suturing the censors' excisions, Braithwaite puts to use "cinephilia's productive disenchantment" and her growing feminist disillusionment with cinema culture in light of the censors' offcuts. ${ }^{4}$ In highlighting repetitions and omissions of international imported films cut by Australian censors, [CENSORED] critiques not only what is censored, but what is made; not only what we have been prohibited from seeing (through censorship of various kinds), but also the troubling tropes that we repeatedly witness and become numb to.

From the film's outset, Braithwaite approaches the material in two different ways: as a historian and artist. On one level, she handles the archive as a historian by observing and foregrounding archival concepts. These practices range from provenance (discussing the origin of the records with the Australian censor, and how they acquired and created the collection), original order (noting the alphabetical arrangement established by the collection's creators), and respect des fonds (drawing purely on this archive as source material for the film, not mixing it with clips of other origins). ${ }^{5}$ But as an artist, she takes creative license with these cornerstone principles of archival practice. Braithwaite unseals and duplicates the clips, reorganises the material (montaged by motif rather than alphabetically sequenced), adds music and voice-over, and shows it to the Australian public for whom - 60 years previously - it was explicitly suppressed. Archival principles protect the integrity of an archive, and yet the film challenges the integrity of the process that brought this archive into being. Indeed, the very intention of [CENSORED] was to liberate this archive of censorship. As a historian, Braithwaite is obliged to observe the archival principles to some degree, but as an "appropriationist", she is compelled to contravene them. The film is forged through this tension. 
In line with archiveology, Braithwaite rearranges, recontextualises, and reframes the archive's documentary traces of censorship through feminist critical practice and commentary "so as to produce new knowledge about cultural history". ${ }^{6}$ In a journey navigated through her exposure to the censors' extensive detritus, Braithwaite's growing disenchantment guides new ways of thinking about the past with the promise of cinephilic liberation from censorship. While the film indeed brings the censored material to light, a darker revelation about cinema's deeply embedded misogyny is produced through the process. Braithwaite's cultural history, in the form of an essay film, effectively conveys the bombardment of repetitive imagery of misogyny and violence in cinema of the period. The viewer experiences this in a condensed manner in her montages, which maximise the affective impact and reframe it through a feminist lens. Braithwaite curates the archive for critical reflection on the history of film (a broader ambition than the initial intention of critiquing censorship). Braithwaite's aim for "us to sit in the trouble of what this archive means, and how this history speaks to us today" reflects Russell's observation that "[i]n archival film practices, the image bank in its fundamental contingency and instability becomes a means by which history can speak back to the present."7 The images' affective nature and monotony express "a proximity to history on the level of experience". 8 Braithwaite's cinephilia turns to "disenchantment" as she grapples with the proximity of the re-encountered past; as in "new cinephilia", for Braithwaite in the archive "the loved object is no longer an immaterial experience" and the films "become more sensuous or tangible as an experience." ${ }^{\prime 9}$ However, in Braithwaite's case, this immediate, sensuous encounter of archival film practice leads to an unexpected - and disillusioned - reframing of mid-twentieth century cinema.

Braithwaite collated and recategorised the collection, collaging the clips into montages of common action while appropriating it to illustrate a feminist perspective on the archive and the body of films it represents. Moments are extracted and compared, akin to the way Maryam 
Tafakory collages looks and gestures that she has extracted from numerous film titles in Iranian cinema in her more recent video, Nazarbazi (2021). As in other essay films, collage is key to the film's critical effect, "as productive tensions and nonlinear narrativity as well as surprising correspondences and repetitions are part of the process." 10 The film is structured thematically into groups of clips that reveal patterns in the era's cinematic action and language, somewhat reminiscent of Tracey Moffatt's frenetic montages of feature film clips, in works such as Love (2003). It uses the logic of both an archivist's categorisation and a supercut, collating clips from different films into sets such as passionate kissing, knife fights, women showering, "indecent sex situations," men slapping women, men beating men, and sexual violence. As critic Lauren Carroll Harris describes:

It piles up, it gets worse: men dragging women by the hair across dining rooms; generic stripteases; women slapped by their partners; gangs of men salivating over a sole woman at parties; peeping Toms... Through this cavalcade of repetition, tropes emerge: beautiful, endangered women demeaned in banal and unimaginative ways. The same types of shots... build toward an aesthetic of entrapment. ${ }^{11}$

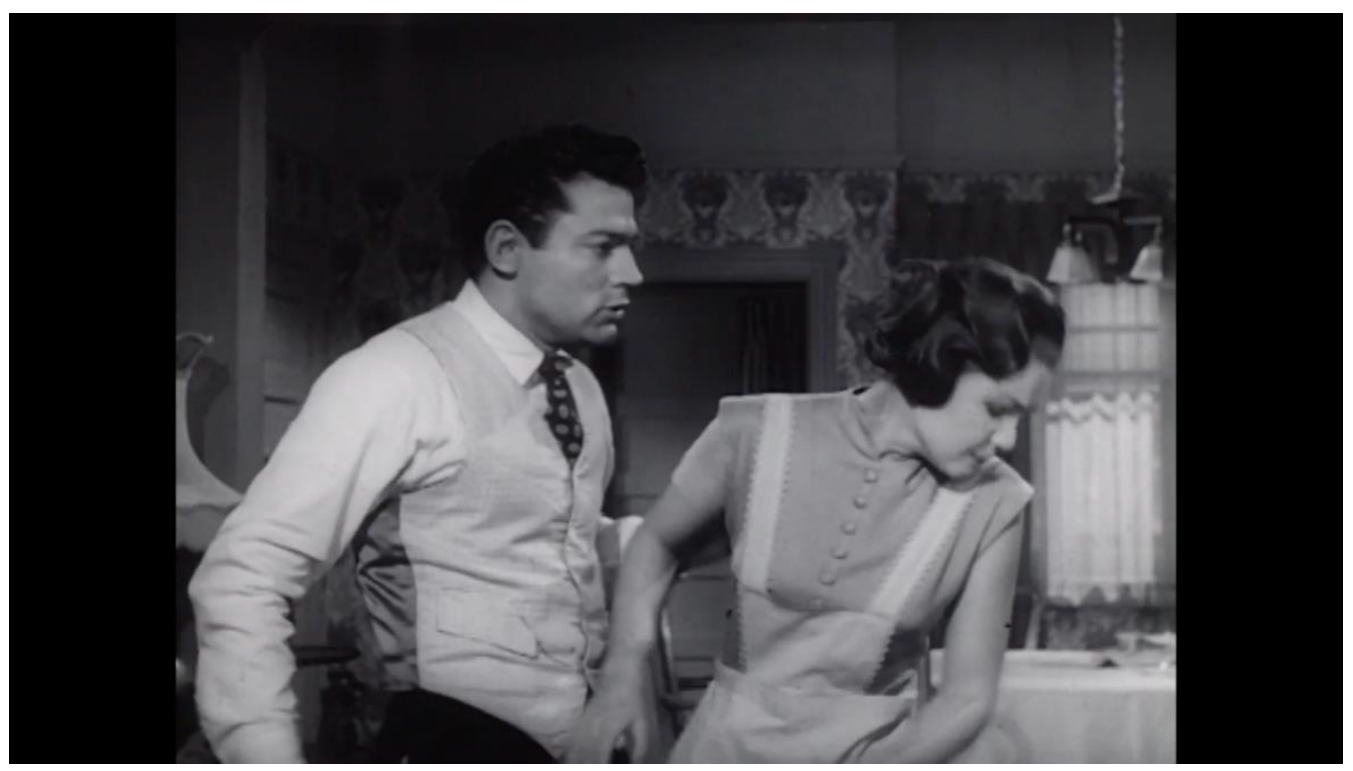



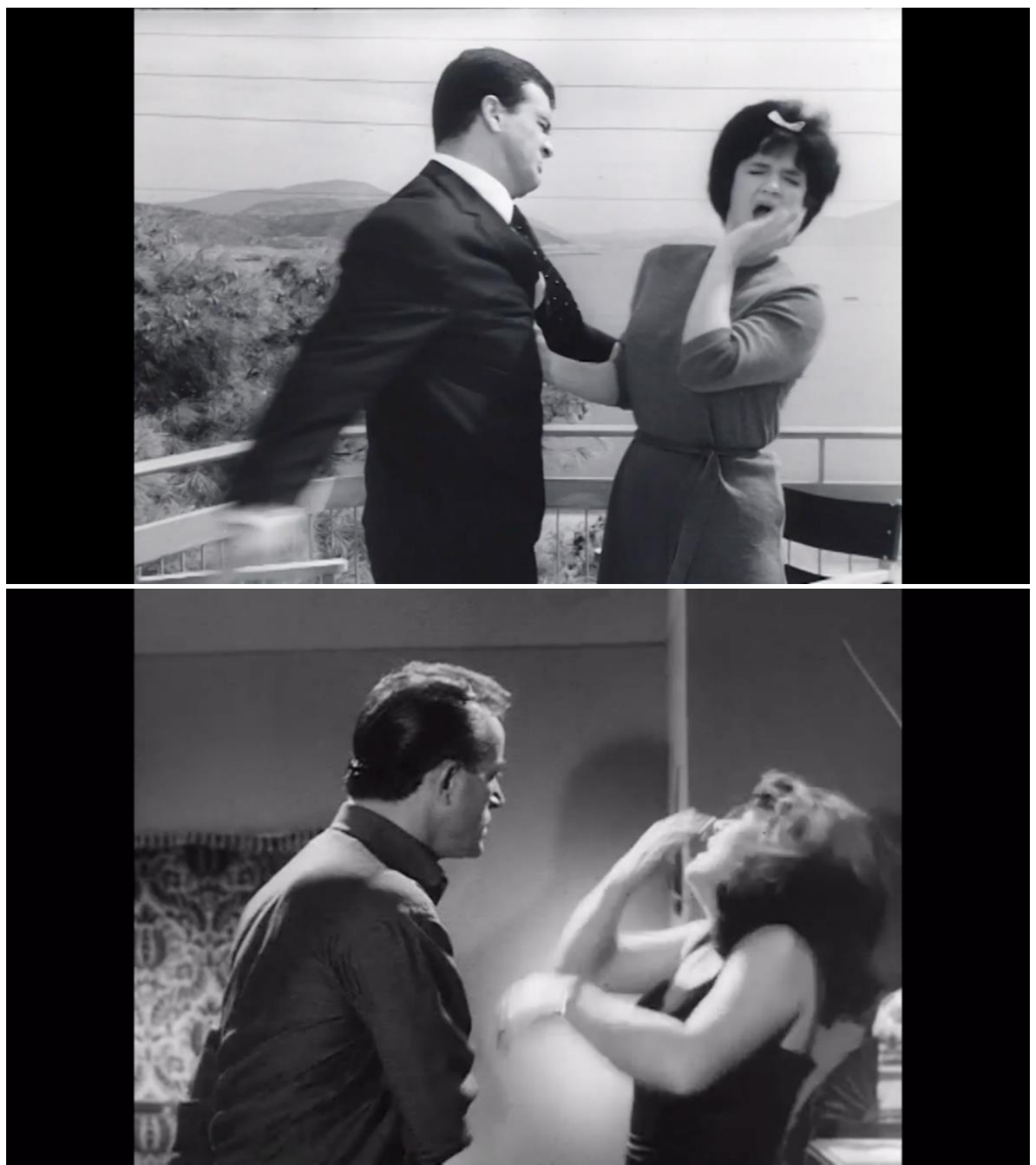

Figures 1-3: In the "Hit a Girl" montage, the repetitive cinematic trope of men slapping women generates a condensed sensory effect that mirrors Braithwaite's experience of viewing the archive. Images from [CENSORED] (Sari Braithwaite, 2018).

Harris' perspective as a viewer echoes Braithwaite's observation of the "sheer unoriginality of these clips side by side" as she spent two years "poring over VHS and DigiBeta copies of the original reels in dark rooms at both the NAA's storage facility in Sydney and the Public Record Office Victoria in Melbourne."12 The montages encapsulate the onslaught of repetitive imagery within the archive, distilling Braithwaite's protracted initial engagement with the collection's unvaried filmic fragments. Feminist historian Ann Curthoys recalls Braithwaite telling her after the film's premiere that “it was the women's faces in the slapping scenes that helped her 
know what the film would be about." ${ }^{, 13}$ Similarly, Braithwaite tells me, "When I was making the film, it was so much about feeling the male gaze in such a visceral way", which similarly highlights how her sensory response to the material - like smarting from the repeated slaps helped shape the film. ${ }^{14}$ The soundtrack contributes to the tenor of the montages (and the moral evaluation of the appropriated clips), with the throbbing ringing under the "Hit a Girl" montage accentuating the nausea of repetition, and the slow instrumental music under "Strip Strip Strip" adding a tragic tone to the fast dancing that it counterpoints. Diegetic audio from the final clip of the sexual violence montage effectively punctuates Braithwaite's message about the cumulative numbing effect of cinema's repetitive misogynistic tropes: "What are you crying for?" says the male perpetrator, "Don't tell me you don't feel anything."

The film's montage structure conveys Braithwaite's phenomenological experience of encountering the archive ("Scene after scene after scene. A single clip is innocuous but seen on repeat it is visceral, and uncomfortable.") and the feminist awakening that the experience led to ("I found my feminism in watching this archive of old film clippings"). ${ }^{15}$ Prior to the film's premiere at the Sydney Film Festival, Braithwaite published a piece in The Guardian reflecting on her shifting relationship with the archive. Initially approaching it with a romantic mission of recovery and redemption, Braithwaite became disillusioned by the drudging nature of her task and by the material itself, which turned out not to be particularly worthy of liberation. As she recounts:

The project began optimistically - I figured I would liberate this archive so audiences could revel in seeing what had been denied. A celebration of democracy, a celebration of cinema. How playful, how irreverent and how cathartic it could be. But after months on end watching this collection, I found I was wearily dragging myself into work. It was a grind, a chore, a commitment to make a film I wished I'd never started... To my surprise, watching these redacted scenes didn't feel liberating - it felt suffocating. ${ }^{16}$ 
From a fantasy of "archive fever" - "a compulsion, repetitive, and nostalgic desire for the archive" - she becomes disillusioned by the prosaic violence of the material that she wades through on her "journey into the archive's heart of darkness". ${ }^{17}$ Rather than seduce, this archive numbs. Consequently, Braithwaite's orientation toward censorship also shifts and she abandons her liberatory goal to focus on deeper undercurrents of cinematic violence than censors' cuts. Having set out to critique the censor, Braithwaite instead found herself uncomfortably complicit with them as she came to also regard the clips as offensive material.

Braithwaite describes herself as "a female filmmaker exploiting the male gaze," but in a more complex way, the film employs a "layered gaze" to draw attention to the misogyny of the cinematic phantasmagoria. ${ }^{18}$ Jaimie Baron identifies a multi-layered structure underpinning works of appropriation, which is based on the viewer's perception of the film's subject, the ethical stance of the original maker, and the ethical stance of the maker who has edited and reframed the material. ${ }^{19}$ [CENSORED] inserts the ethics of the censor's gaze into this multilayered structure, exploring both contrasts and complicity between different layers of the gaze regarding the material. As Harris notes, “[t]he film is freighted with its maker's searching and questing and navigating the ethical puzzles of her own role as filmmaker, censor and viewer." 20 The voice-over is an audio guide to the layers of the gaze, foregrounding the artist's personal gaze and journey but also pointing to the existence and tensions between other layers, such as the original filmmakers' gaze and the censors' gaze (who determined the start and endpoints of the clips and their inclusion in the archive). The censors' gaze is further explained by intertitles quoting the censorship board's documents and decisions. 
Reduce close-up shots of man's staring eyes as he watches girl in shower.

Delete shots of nude girl.

Australian Censorsbip Board

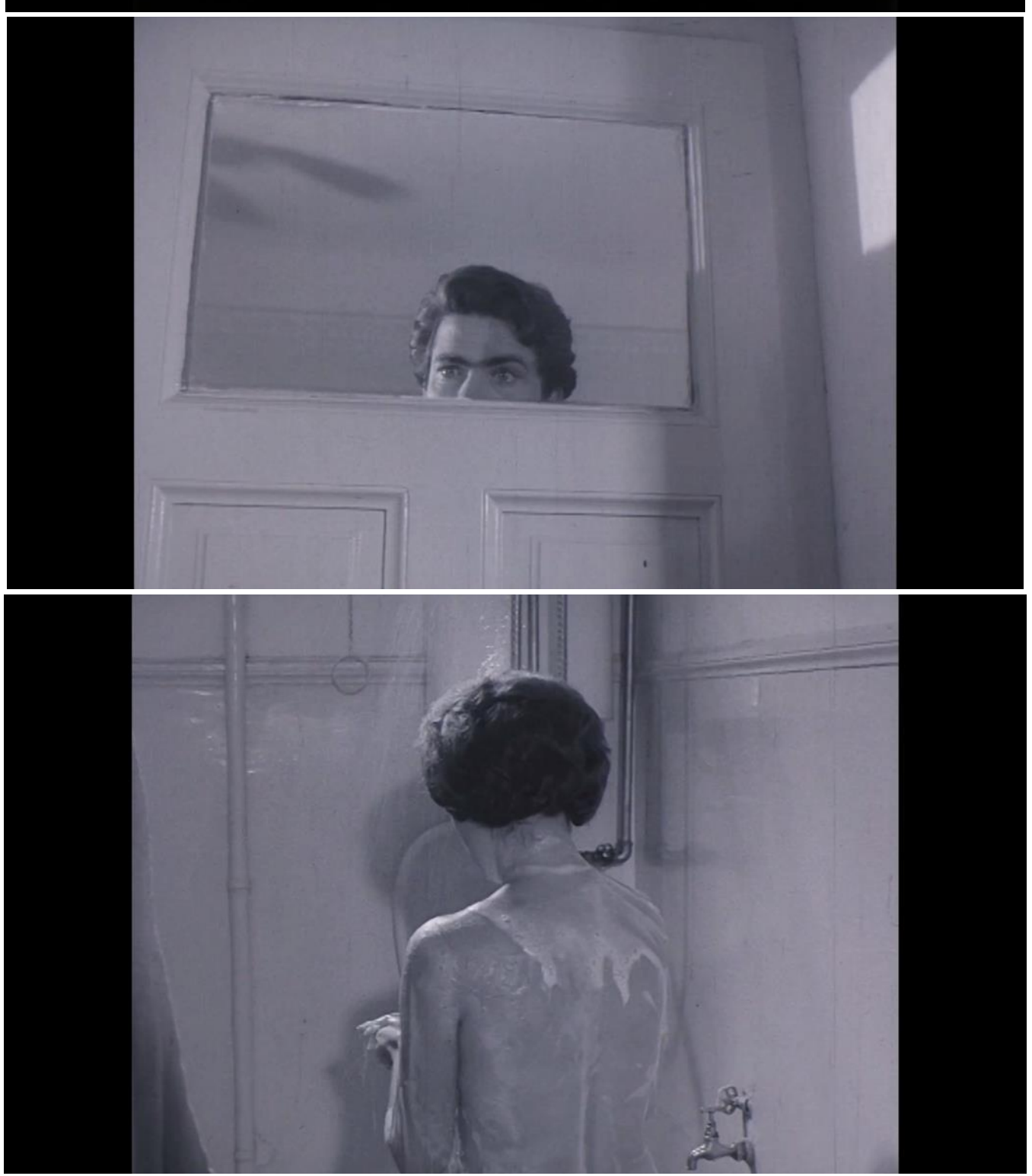

Figures 4-6: Intertitles quoting the censorship board's documents and decisions provide insight into the censors' gaze. Images from [CENSORED] (Sari Braithwaite, 2018). 
Baron's concept of the layered gaze makes clear why Braithwaite grappled with the material in the way that she did. The appropriation of this archival material involves not simply two layers (the gazes of the appropriationist - i.e., Braithwaite herself - and the original filmmakers) but three layers, with the censor's gaze as a significant layer in between. Braithwaite set out to engage with the censor's gaze, to trace their censorial sensitivities through the fragments they left behind. Yet the nature of the material and her experience as a viewer leads her to grapple with the (pervasively misogynistic) gaze of the original filmmakers in a dynamic common to appropriationist practices discussed by Baron. Braithwaite described "feeling overwhelmed by what I had seen", leading to a shift in focus from censor to viewer:

I wanted to challenge people about what they [sic] watching. So much of the content you don't even notice in the context of the film, you just let it wash over you, but there's a cumulative effect of repetition and in ways of telling stories the same way over and over again. I think that kind of makes us complacent to a whole bunch of dodgy stuff. ${ }^{21}$

The affective and creative processes of Braithwaite's project involved self-reflection on her relationship to prior gazes and posing similar questions for the viewer, implicating them in the gazes at work. The viewer is implicated in voyeuristic and fetishistic looks in the film's "Peeping Tom" and "Strip Strip Strip" montages, with the voice-over describing the onscreen spectator who "lurks in so many of these deleted frames" (watching women bathe, undress, or dance) as "the mirror being held up to us". The final montage, "The Spectator", is introduced with the voice-over's final words, "we can only ask ourselves: what is it that we are spectators to?" further underscoring spectatorial complicity by featuring on-screen spectators. [CENSORED] is then underpinned by the ethical negotiation described by Baron, which involves unpacking the layers of the gaze so the viewer can reflect on - and make decisions about - their own complicity. ${ }^{22}$ Braithwaite was ultimately concerned with this complicity that bleeds across layers of the gaze and across history to reflect on the present. 

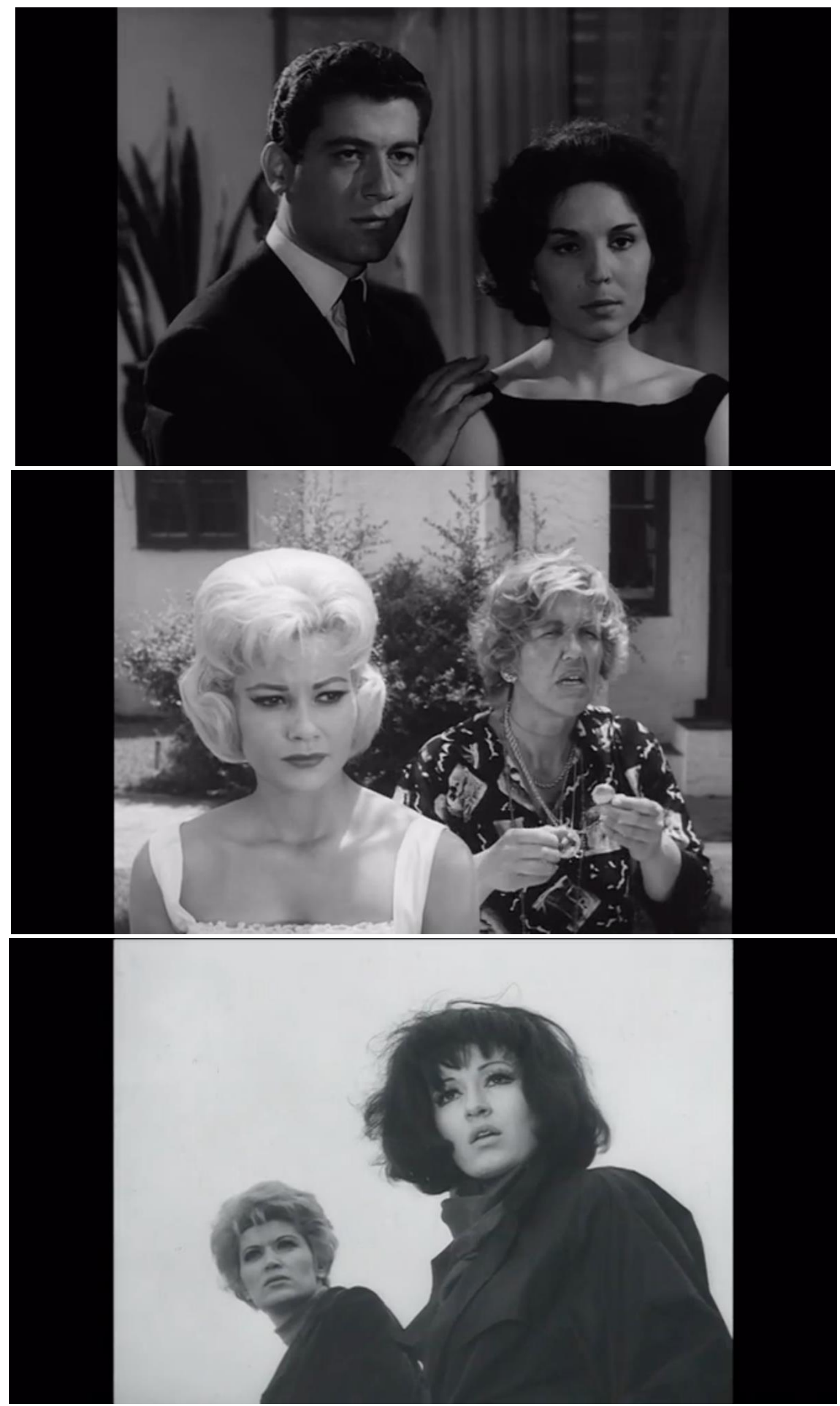

Figures 7-9: The final montage, "The Spectator", underscores spectatorial complicity by featuring on-screen spectators. Images from [CENSORED] (Sari Braithwaite, 2018). 
Scholar-practitioners of artists' moving image, Lucy Reynolds and Emma Cocker, have both reflected on the complex role of the artist working with found footage and archival material. Reynolds has highlighted the dual role of a found footage filmmaker as an "archaeologist/archivist and critical interventionist" who excavates the layers of histories and, through their interventions, reveals previously obscured significance and histories, distinct from the original messages of the material. ${ }^{23}$ To use Cocker's term, Braithwaite takes "ethical possession" of the archive in this dual role, excavating its fragments with a twofold purpose, both "to rescue or recuperate value for lost fragments and write them back into history" while simultaneously working to reveal instances of "deliberate exclusion within the archive omissions, gaps and imbalances." ${ }^{24}$ Braithwaite was not expecting this latter purpose to emerge from her engagement with the archive, but it came to be the key takeaway of the film's intraand extra-textual narrative. Reflecting Russell's observation that found images always refer back to the context of their original production, albeit sometimes obliquely, the archival collection of censors' cuttings inadvertently pointed Braithwaite to an original production context designed almost exclusively by and for men. ${ }^{25}$ This attention to the production context of the past resonates in the present, considering the appearance of [CENSORED] amidst the contemporary moral reckoning regarding misogyny and sexual violence in the film industry.

Braithwaite becomes not a liberator but an excavator (in the sense used by Reynolds and Cocker), digging out discarded remnants to examine them from a present-day perspective and create a counter-hegemonic narrative with "dissenting or resistant" forms of cultural memory. ${ }^{26}$ Beyond the film trailer's enticement to "enter a forbidden archive" and "see the unseen", [CENSORED] manipulates this archive to offer new ways of sensing (censored) cinema and seeing its tired tropes. Russell, on the potential of archiveology, proposes that "fragments... of classical narrative films might constitute an awakening of women from the long sleep of mid- 
twentieth-century cinema" and [CENSORED] awakens the viewer to a new history of the period's cinema through the censor-curated scraps in the archive. ${ }^{27}$

Like the archive-based films explored in the final chapter of Russell's Archiveology, [CENSORED] offers an example of "awakening from the archive and détourning its gender politics". ${ }^{28}$ The feminist awakening occurred at a personal level for Braithwaite as she tackled the archive, spending weeks on end watching objectionable deleted scenes:

It was initially chaotic - almost meaningless stimulus on loop. But then I started to identify the patterns, the repetition, the tropes and I found something deeply disturbing. These stray fragments were screaming an unexpected message - and it wasn't about government censorship. I was drowning in an archive of a dominating, violent gaze: a male gaze. And I hated it. ${ }^{29}$

By "drowning" in this archive, Braithwaite awakens to its nature as "a distilled catalogue of the destructive patriarchal imaginary" accidentally created by the censors (or what she bluntly calls in the film "a state-sanctioned spank bank"). ${ }^{30}$ Braithwaite uses montage to replicate this sensory experience - and concomitant realisation - in the spectator. In watching the film, one is hammered by the male gaze. It is through repetition that it is revelatory. For example, as Harris describes, in watching the sexual violence montage, "we realise the extent to which these scenes have been aestheticised from the vantage point of the rapist." 31 As Catherine Fowler shows in her study of videographic (feminist) diptychs, comparison operates as an affective stance and a strategy that is useful to think with, in both audio-visual and feminist ways. $^{32}$ [CENSORED] deploys comparison as a key strategy through its series of supercuts, highlighting the similarity of cinematic action across censored films of the period. 

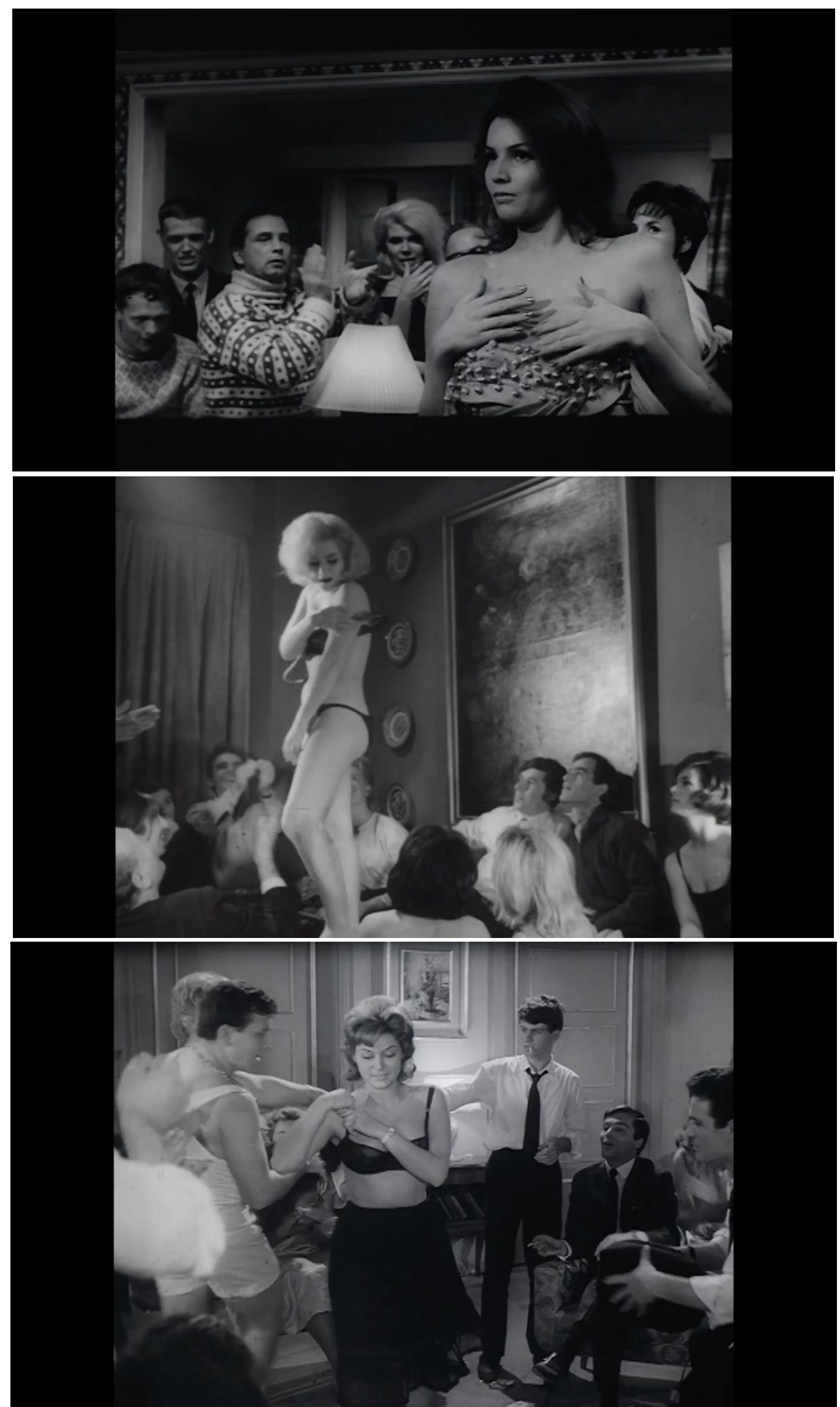

Figures 10-12: In "Strip, Strip, Strip" and other montages, comparison is a key strategy for highlighting the similarity of cinematic action across censored films of the period. Images from [CENSORED] (Sari Braithwaite, 2018). 
[CENSORED] epitomises the way archiveology can affect an "awakening" from the gendered corpus of film history. ${ }^{33}$ As a trained historian working as an artist in the essay film, Braithwaite is uniquely placed to undertake such an awakening. As Russell notes of Walter Benjamin: “it is the crystallization of the critic in the historian that lies at the heart of the 'awakening' that he consistently calls for." ${ }^{34}$ [CENSORED] uses the archive for détournement - already cut by the censor, Braithwaite then cuts the film clips out of their alphabetical arrangement in a hidden archive, recombining them in a surprising way for a politically educative purpose. Namely, she montages their misogynistic tropes to reveal the sensory and ideological effects of well-worn cinematic clichés. The montages foreground recurrence, enabling the viewer to both see and feel the impacts of gender-based imagery of sex and violence that is both passé and present in our cinematic imaginary.

\section{Notes}

${ }^{1}$ Jaimie Baron, Reuse, Misuse, Abuse: The Ethics of Audiovisual Appropriation in the Digital Era (New Brunswick: Rutgers University Press, 2020).

${ }^{2}$ Catherine Russell, Archiveology: Walter Benjamin and Archival Film Practices (Durham, NC: Duke University Press, 2018), 25.

${ }^{3}$ Russell, Archiveology, 174.

${ }^{4}$ Thomas Elsaesser, "Cinephilia, or the Uses of Disenchantment," in Cinephilia: Movies, Love and Memory, edited by Marijke De Valck and Malte Hagener (Amsterdam: Amsterdam University Press, 2005), 27-43.

${ }^{5}$ Laura A. Millar, Archives: Principles and Practices. $2^{\text {nd }}$ edn. (London: Facet Publishing, 2017), $45-$ 50 .

${ }^{6}$ Russell, Archiveology, 25.

${ }^{7}$ Sari Braithwaite, "[CENSORED] was meant to celebrate freedom. Instead it exposes something darker." The Guardian, 30 May 2018. https://www.theguardian.com/film/2018/may/30/censored-wasmeant-to-celebrate-freedom-instead-it-exposes-something-darker; Russell, Archiveology, 50.

${ }^{8}$ Russell, Archiveology, 102.

${ }^{9}$ Elsaesser, "Cinephilia, or the Uses of Disenchantment," 38.

${ }^{10}$ Russell, Archiveology, 24.

${ }^{11}$ Lauren Carroll Harris, "Progressives and Puritans: [CENSORED] and Cinema's Moral Reckoning," Kill Your Darlings, 2 July 2018. https://www.killyourdarlings.com.au/article/progressives-andpuritans-censored//

${ }^{12}$ Sari Braithwaite, [CENSORED] (Arenamedia/Icarus Films, 2018); Anthony Carew, "Cut-up Country: The Polemics of Presentation in [CENSORED] and Terror Nullius," Metro Magazine: Media \& Education Magazine 198 (2018): 96.

${ }^{13}$ Ann Curthoys cited in John Docker, Growing Up Communist and Jewish in Bondi. Volume 3: I Am Born (Melbourne, Australia: Kerr Publishing, 2020). 
${ }^{14}$ Sari Braithwaite, email to author, 1 February 2022.

${ }^{15}$ Braithwaite, "[CENSORED] was meant to celebrate freedom."

${ }^{16}$ Braithwaite, "[CENSORED] was meant to celebrate freedom."

${ }^{17}$ Jacques Derrida, "Archive Fever: A Freudian Impression," trans. Eric Prenowitz, Diacritics 25, no.

2 (Summer 1995): 57; Carew, "Cut-up Country," 97.

${ }^{18}$ Braithwaite, "[CENSORED] was meant to celebrate freedom."

${ }^{19}$ Baron, Reuse, Misuse, Abuse, 16-17.

${ }^{20}$ Harris, "Progressives and Puritans."

${ }^{21}$ Braithwaite in James Croot, "[CENSORED]: How an Australian Documentarian's Hunt for Cinematic Treasure Turned into a Sexist Nightmare," Stuff, 1 August 2018.

https://www.stuff.co.nz/entertainment/film/105921916/censored-how-an-australian-documentarianshunt-for-cinematic-treasure-turned-into-a-sexist-nightmare.

${ }^{22}$ Jaimie Baron in Bruno Guaraná, "Reuse, Misuse, Abuse: A Conversation with Jaimie Baron," Film Quarterly 72, no. 2 (Winter 2020): 110.

${ }^{23}$ Lucy Reynolds, "Outside the Archive: The World in Fragments," In Ghosting: The Role of the Archive within Contemporary Artists' Film and Video, edited by Jane Connarty and Josephine Lanyon (Bristol: Picture This Moving Image, 2006), 15-16.

${ }^{24}$ Emma Cocker, "Ethical Possession: Borrowing from the Archives," In Cultural Borrowings: Appropriation, Reworking, Transformation, edited by Iain Robert Smith (A Scope e-Book, 2009), 99100.

${ }^{25}$ Catherine Russell, Experimental Ethnography: The Work of Film in the Age of Video (Durham, NC: Duke University Press, 1999), 238.

${ }^{26}$ Cocker, "Ethical Possession," 100.

${ }^{27}$ Russell, Archiveology, 197.

${ }^{28}$ Russell, Archiveology, 34.

${ }^{29}$ Braithwaite, "[CENSORED] was meant to celebrate freedom."

${ }^{30}$ Braithwaite, "[CENSORED] was meant to celebrate freedom."

${ }^{31}$ Harris, "Progressives and Puritans."

${ }^{32}$ Catherine Fowler, "Expanding the Field of Practice-Based-Research: The Videographic (Feminist)

Diptych," Media Practice and Education 22, no. 1 (2021), 58.

${ }^{33}$ Russell, Archiveology, 184-217.

${ }^{34}$ Russell, Archiveology, 42.

\section{Bibliography}

Baron, Jaimie. Reuse, Misuse, Abuse: The Ethics of Audiovisual Appropriation in the Digital Era. New Brunswick, NJ: Rutgers University Press, 2020.

Braithwaite, Sari. “[CENSORED] was meant to celebrate freedom. Instead it exposes something darker.” The Guardian, 30 May 2018.

https://www.theguardian.com/film/2018/may/30/censored-was-meant-to-celebratefreedom-instead-it-exposes-something-darker

Carew, Anthony. "Cut-up Country: The Polemics of Presentation in [CENSORED] and

Terror Nullius.” Metro Magazine: Media \& Education Magazine 198 (2018): 94-101. 
Cocker, Emma. "Ethical Possession: Borrowing from the Archives." In Cultural Borrowings: Appropriation, Reworking, Transformation, edited by Iain Robert Smith, 92-110. A Scope e-Book, 2009.

Croot, James. “[CENSORED]: How an Australian Documentarian's Hunt for Cinematic Treasure Turned into a Sexist Nightmare.” Stuff, 1 August 2018. https://www.stuff.co.nz/entertainment/film/105921916/censored-how-an-australian$\underline{\text { documentarians-hunt-for-cinematic-treasure-turned-into-a-sexist-nightmare }}$

Derrida, Jacques. “Archive Fever: A Freudian Impression.” trans. Eric Prenowitz. Diacritics 25, no. 2 (Summer 1995): 9-63.

Elsaesser, Thomas. "Cinephilia, or the Uses of Disenchantment." In Cinephilia: Movies, Love and Memory, edited by Marijke De Valck and Malte Hagener, 27-43. Amsterdam: Amsterdam University Press, 2005.

Fowler, Catherine. "Expanding the Field of Practice-Based-Research: The Videographic (Feminist) Diptych.” Media Practice and Education 22, no. 1 (2021): 49-60.

Guaraná, Bruno. “Reuse, Misuse, Abuse: A Conversation with Jaimie Baron.” Film Quarterly 72, no. 2 (Winter 2020): 106-112.

Harris, Lauren Carroll. "Progressives and Puritans: [CENSORED] and Cinema's Moral Reckoning.” Kill Your Darlings, 2 July 2018.

\section{https://www.killyourdarlings.com.au/article/progressives-and-puritans-censored/}

Millar, Laura A. Archives: Principles and Practices. $2^{\text {nd }}$ ed. London: Facet Publishing, 2017. Reynolds, Lucy. "Outside the Archive: The World in Fragments." In Ghosting: The Role of the Archive within Contemporary Artists' Film and Video, edited by Jane Connarty and Josephine Lanyon, 14-23. Bristol: Picture This Moving Image, 2006.

Russell, Catherine. Archiveology: Walter Benjamin and Archival Film Practices. Durham, NC: Duke University Press, 2018. 
Frames Cinema Journal, Issue 19 (March 2022)

Russell, Catherine. Experimental Ethnography: The Work of Film in the Age of Video.

Durham, NC: Duke University Press, 1999.

\section{Filmography}

Braithwaite, Sari. [CENSORED]. Arenamedia/Icarus Films, 2018.

Braithwaite, Sari. Smut Hounds. Ronin Films, 2015.

\section{Author Biography}

Claire Henry is a Senior Lecturer in Digital Media Production at Massey University in Wellington, Aotearoa New Zealand. Her publications include the forthcoming co-authored monograph Screening the Posthuman (Oxford University Press), Revisionist Rape-Revenge: Redefining a Film Genre (Palgrave Macmillan, 2014), and journal articles in Journal of Digital Media \& Policy, Cine-Excess, Porn Studies, Open Cultural Studies, Senses of Cinema, Studies in European Cinema, and Ctrl-Z: New Media Philosophy. 